\title{
The effects of bauxite/alumina waste on the composition of the macroinvertebrate community of the Rio Cobre, a major river in Jamaica
}

\author{
Eric Joseph Hyslop ${ }^{1,2}$ \& Damian Arjan Nesbeth ${ }^{1}$ \\ ${ }^{1}$ Department of Life Sciences, University of the West Indies, Mona campus, Kingston 7, Jamaica \\ ${ }^{2}$ Corresponding author: Eric Joseph Hyslop, e-mail: eric.hyslop@uwimona.edu.jm
}

HYSLOP, E. J. \& NESBETH, D. A. The effects of bauxite/alumina waste on the composition of the macroinvertebrate community of the Rio Cobre, a major river in Jamaica. Biota Neotrop. 12(2): http:// www.biotaneotropica.org.br/v12n2/en/abstract?article+bn00512022012

\begin{abstract}
The paper sets out the results of a one year study on the effects of bauxite waste discharge on the macroinvertebrate fauna of a Jamaican river, the Rio Cobre, based on monthly samples from four sites. Significantly higher levels of temperature and conductivity were found at the sites downstream of the point of effluent discharge. The invertebrate fauna of the two sites immediately downstream of the point of discharge was dominated by two invertebrate taxa: Baetis sp. (Fam. Baetidae) and Smicridea jamaicensis (Fam. Hydropsychidae). These taxa made up between 26 to $35 \%$ of the numbers at these two sites. Upstream of the bauxite waste input the community was dominated by cased caddis larvae of Helicopsyche ochthephila (Fam. Helicopsychidae) and Cubanoptilia tridens (Fam. Glossostomatidae), which also occurred at the site furthest downstream from the waste input. Scrapers dominated at the upstream site whereas collector gatherers were the predominant functional feeding category at the impacted sites. The constituents of the bauxite waste are discussed and it is proposed that the changes in faunal composition which have resulted from waste input may be a consequence of habitat alteration due to increased deposits of suspended material rather than the chemical nature of the waste.

Keywords: habitat alteration, metal waste, Caribbean rivers, faunal composition, Trichoptera.
\end{abstract}

HYSLOP, E. J. \& NESBETH, D. A. Os efeitos da bauxita/alumina resíduos sobre a composição da Comunidade de macroinvertebrados cobre o Rio, dos principais rios da Jamaica. Biota Neotrop. 12(2): http://www. biotaneotropica.org.br/v12n2/pt/abstract?article+bn00512022012

Resumo: O livro apresenta os resultados de um estudo de um ano sobre os efeitos das descargas de resíduos de bauxita sobre a fauna de macroinvertebra de um rio jamaicano, o Cobre de Rio, com base em amostras mensais de quatro sites. Significativamente maiores níveis de temperatura e condutividade foram encontrados nos locais a jusante do ponto de descarga de efluente. A fauna de invertebrados dos dois sites imediatamente a jusante do ponto de descarga foi dominada por dois táxons de invertebrados: Baetis SP. (Fam. Baetidae) e Smicridea jamaicensis (Fam. Hydropsychidae). Esses táxons compostas entre 26 a 35\% dos números nesses dois locais. A montante da entrada de resíduos de bauxita da Comunidade foi dominada por larvas de caddis preto de Helicopsyche ochthephila (Fam. Helicopsychidae) e Cubanoptilia tridens (Fam. Glossostomatidae), que também ocorreu no local mais a jusante da entrada dos resíduos. Raspadores de dominam o site enquanto coletoras de coletores são a categoria alimentação funcional predominante.

Palavras-chave: alteração do habitat, resíduos de metal, rios caribenhos, composição da fauna, Trichoptera. 


\section{Introduction}

There has been no significant study on the effects of anthropogenic disturbance on the invertebrate fauna of Jamaican rivers. In fact there is very little study of the basic composition and biology of this faunal component in general. Some exceptions to this are studies of the fauna of relatively uncontaminated rivers (Boon et al. 1986) and postgraduate theses (eg Fender 2001). Published information on the effects of bauxite waste on freshwater invertebrates is also sparse. Fonseca and Esteves (1999) found that sites in an Amazonian lake that had been contaminated with bauxite tailings had lower densities of oligochaetes, bivalves, ostracods and chironomid larvae when compared to unimpacted locations in the same lake. Densities of the ephemeropteran Campsurus were greater at bauxite waste-impacted sites. Callisto et al. (1998) also found lower densities of chironomids at bauxite waste contaminated sites in a small river in Amazonia, Brazil.

Jamaica is recognized as the third largest producer of bauxite and processed alumina in the world (Library...2011), although since 2009 three of the four major producers have scaled back operations due to a slump in global demand and the sectors' overall contribution to GDP has been declining (US Department...2010).

Extraction of aluminium from bauxite ore is achieved by digestion of the ore with hot caustic soda $(\mathrm{NaOH})$ under pressure. The end product of this process is a slurry of aluminate ions which is separated by filtration from a mixture of basic iron and silicon oxides, commonly known as "red mud". During processing, the mud is washed several times to recover caustic soda and aluminates. The waste has high alkalinity and also high sodium content. Typically, highly elevated values of $\mathrm{pH}, \mathrm{Na}^{+}$concentration, $\mathrm{Al}^{3+}$ concentration and alkalinity have been recorded from the wastewater released into the Rio Cobre, the river being studied here, from the bauxite processing plant located upstream (Parkin 1993). The waste water which is released typically has an elevated temperature greater than $30{ }^{\circ} \mathrm{C}$ since it is also used to cool the mud.

The idea that macroinvertebrate community structure reflects contamination levels in a freshwater body is a basic tenet in biomonitoring studies (Cairns \& Pratt 1993). Because benthic macroinvertebrates are continuously exposed to conditions they serve to integrate the effects of contaminants over time and provide a measure of water quality. Macroinvertebrates are frequently used as bioindicators of pollution in freshwaters for a number of other reasons, (Cain et al. 1992). These include the fact that they are largely sedentary organisms whose presence or absence is often a good indication of conditions in the area. They are easily collected with the minimum of apparatus and in most cases identification to family level is all that is required (Abel 1996).

Studies which have looked at the effects of mine waste on macroinvertebrates in rivers generally show that the main effect on the community is a reduction of richness and diversity (Maret et al. 2003). Biomass and density of individual species however may be increased (Goto \&Wallace 2009). Macroinvertebrates take up metals from the water or sediment or as part of their diet (Wayland \& Crossley 2006). Several studies have noted a change in species composition of invertebrates at sites receiving mining effluent. (Sprague et al. 1965, Winner et al. 1980, Lynch et al. 1988) For example, mayflies which typically dominated unimpacted sites of the Arkansas river were largely replaced by Orthocladinae chironomid larvae and trichopterans such as Hydropsyche at sites which received contamination from mine waste (Clements 1994).

This study examines the effects of the input of waste from a bauxite processing facility on the composition of the macroinvertebrate fauna of the upper Rio Cobre, a major Jamaican river.

\section{Method}

The Rio Cobre is one of the largest rivers in Jamaica, at $30 \mathrm{~km}$ in length, with an extensive watershed $\left(1256 \mathrm{~km}^{2}\right)$, (Andrews et al. 2001). It enters the sea at Hunt's Bay slightly to the west of Kingston Harbour, Jamaica's principal shipping port. The river receives bauxite processing waste in the upper reaches from a nearby bauxite processing plant. Four sampling sites were chosen for study, one (Black River) directly above the point of entry of the waste, located on a side stream to the main river channel, and three at varying distances downstream of effluent input in the main channel (Victoria $2.5 \mathrm{~km}$, Linstead $5.5 \mathrm{~km}$, and Deeside $12 \mathrm{~km}$, downstream of the effluent input). The Black River site was used as the reference for comparison with the downstream sites even although it differed in certain characteristics; principally stream order and extent of bankside vegetation cover. Differences in substrate composition were thought to result from the effects of the bauxite waste. There was no site directly upstream which corresponded more closely to the bauxite waste contaminated locations.

Monthly samples were taken for a period of 13 months at all four sites between May 1999 and June 2000. The sampling technique used to estimate species composition and abundance was a combination of 2 minute kick samples using a standard bottom kick net of $500 \mu \mathrm{m}$ mesh size and quadrat samples of $0.09 \mathrm{~m}^{-2}$ area and $900 \mu \mathrm{m}$ mesh. All sampling was conducted in riffles and a total of 4 samples were collected on each sampling occasion. All invertebrates collected were preserved in $10 \%$ formalin solution for subsequent identification and enumeration in the laboratory. For purposes of analysis of taxonomic composition monthly samples were pooled as there was little seasonal variation in faunal composition at a particular site. Monthly results were used in calculation of two indices, which use different models as the basis for estimating diversity, as follows:

Simpson's Index (D) (Equation 1):

$$
\mathrm{D}=1-\frac{\sum \mathrm{n}_{\mathrm{i}}\left(\mathrm{n}_{\mathrm{i}}-1\right)}{\mathrm{N}(\mathrm{N}-1)}
$$

Shannon Weaver Index (H) (Equation 2):

$$
\mathrm{H}=-\sum \frac{\mathrm{n}_{\mathrm{i}}}{\mathrm{N}} \ln \frac{\mathrm{n}_{\mathrm{i}}}{\mathrm{N}}
$$

where: $\mathrm{N}=$ the number of individuals in a sample from the community; $\mathrm{n}_{\mathrm{i}}=$ the number of individuals in a species $i$ of a sample from a community

Similarity indices were also used to compare macroinvertebrate composition between sites on a monthly basis (Sørensen 1957) (Equation 3):

$$
\text { Percentage Similarity }=2 Z /(X+Y) \times 100
$$

where: $\mathrm{X}=$ number of taxa in community a; $\mathrm{Y}=$ number of taxa in community $b ; Z=$ number of taxa common to communities $a$ and $b$.

Physico-chemical data were collected on each sampling occasion as follows: dissolved oxygen and water temperature using a $\mathrm{YSI}^{\mathrm{TM}}$ (Yellow Springs Instruments) 55 meter and conductivity and $\mathrm{pH}$ using a YSI 60 meter.

All statistical testing of data was carried out using Statistica ${ }^{\circledR}$ version 6.0, 1998. Physico-chemical data from different sites were pooled for all months of collection as no significant temporal variation in parameter values was found. Data were compared using one-way analysis of variance in conjunction with post hoc analysis using the Tukey test. Stepwise regression analyses were also performed to analyse the relationships between the physico-chemical 
parameters (dissolved oxygen, $\mathrm{pH}$, temperature, and conductivity), and a) invertebrate taxonomic richness; b) invertebrate abundance/ percentage frequency; and c) Simpson's diversity indices at each site.

Chi-square tests were carried out using a $2 \times 2$ contingency table developed in Microsoft Excel to analyze whether observed differences in the proportions of the functional feeding groups (scrapers and collectors) between Black River and the other three sites were statistically significant.

\section{Results}

Table 1 shows the mean values of the recorded physico-chemical parameters based on monthly samples. It is apparent that, while $\mathrm{pH}$ does not vary significantly among the four sites, the Black River site, upstream of the effluent input, has significantly lower values of temperature $(\mathrm{p}<0.05)$, and conductivity is about $50 \%$ that of the other three sites $(p<0.05)$. Similarly dissolved oxygen levels are significantly lower $(\mathrm{p}<0.05)$ at the Victoria site immediately downstream of the point of effluent input (All tested by one-way Analysis of Variance). Regression analyses revealed a slight positive relationship between diversity and $\mathrm{pH}\left(\mathrm{R}^{2}=0.23\right.$ at $\left.\mathrm{p}=0.032\right)$. However, no other statistically significant associations were found between physicochemical parameters ( $\mathrm{pH}$, dissolved oxygen, temperature and conductivity) and biological descriptors (diversity, taxonomic richness or abundance) at the $95 \%$ probability level.

As depicted in Figure 1, overall, the macroinvertebrate assemblage at Black River was different from that found at Victoria,

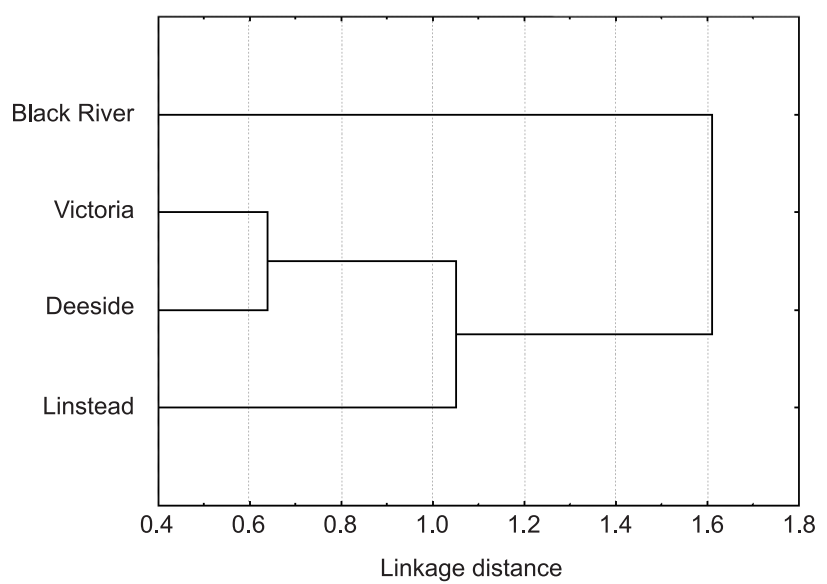

Figure 1. Tree diagram showing clustering of sites to highlight similarities in macroinvertebrate taxonomic compositions (using single linkage; Euclidean distances) across four sites on the upper Rio Cobre, Jamaica.
Linstead and Deeside. Also the proportions of the component taxa of the invertebrate fauna at the Victoria and Linstead sites were different from Black River (Table 2). Baetis sp., (family Baetidae) and Smicridea jamaicensis, (family Hydropsychidae) predominated at the impacted sites.

There was a low representation of cased Trichoptera, particularly Helicopsyche ochthephilia (Fam. Helicopsychidae) at these sites, and an absence of Haegulus jamaicensis (Fam. Leptophlebiidae), at Victoria. Among the gastropod molluscs there was replacement of Thiara granifera by Melanoides tuberculata (both Fam. Thiaridae) at the Victoria and Linstead sites and a decline in the importance of Spilochamys sp. (Fam. Hydrobiidae) relative to Physella jamaicensis (Fam. Physidae), which became increasingly abundant at the impacted sites. These trends are reversed at Deeside, $12 \mathrm{~km}$ below the waste input point, possibly indicating a return to a less disturbed community.

The mean monthly values for the Shannon Weaver and Simpsons diversity indices showed the highest values for Deeside whereas taxonomic richness was slightly higher at the Victoria and Linstead sites. Table 3 summarises the mean monthly similarity coefficients showing increasing similarity to the fauna of Black River with increasing distance downstream from the point of effluent input but also the greatest level of similarity between the Victoria and Linstead sites.

Functional feeding groups of invertebrates as defined by Cummins (1995) are considered important in many models of stream ecosystems. Although published information is largely lacking for neotropical species, we assigned the various taxa collected to FFG's using existing information (Merrit \& Cummins 1996, Tomanova et al. 2006) and our own conclusions based upon microscopic examination of the structure of the mouthparts. The prevalence of the groups at the four sites is shown in Figure 2. Notable is the inverse relationship between scrapers and collectors at the first three sites with predominance of the former at Black River and of the latter category, particularly at the Victoria and Linstead sites. When compared with Black River, the proportion of invertebrates belonging to the collector and scraper functional feeding groups were significantly different at Victoria $\left(\chi^{2}=5.86 \times 10^{-18}, \mathrm{p}<0.05\right.$, df $\left.=1\right)$, Linstead $\left(\chi^{2}=1.83 \times 10^{-19}, \mathrm{p}<0.05, \mathrm{df}=1\right)$, and Deeside $\left(\chi^{2}=3.98 \times 10^{-09}\right.$, $\mathrm{p}<0.05$, df = 1).

\section{Discussion}

Based on physico-chemical criteria the main effects at the bauxite waste-impacted sites are significant increases in temperature and conductivity. In the former case the differences need to be interpreted with caution as the amount of bankside vegetation cover at Black River is greater and this would help maintain a lower water

Table 1. Mean values of physico-chemical parameters recorded at four sites on the upper Rio Cobre over a 13 month period. Range of recorded values is shown in parentheses $(\mathrm{n}=12)$.

\begin{tabular}{|c|c|c|c|c|}
\hline Parameter/Site & Black River & Victoria & Linstead & Deeside \\
\hline Water Temperature ${ }^{\circ} \mathrm{C}$ & 24.5 & 26.5 & 27.5 & 27 \\
\hline \multirow{3}{*}{ Dissolved Oxygen $\mathrm{mgL}^{-1}$} & $(20.5-25.5)$ & $(22.5-26.3)$ & $(23.1-27.2)$ & $(22.1-27.8)$ \\
\hline & 8.75 & 6.8 & 7.5 & 7.83 \\
\hline & $(6.80-9.23)$ & $(4.5-7.90)$ & $(5.1-8.25)$ & $(6.25-8.44)$ \\
\hline \multirow[t]{2}{*}{$\mathrm{pH}$} & 8.5 & 8 & 7.9 & 8 \\
\hline & $(8.2-8.5)$ & $(7.8-8.4)$ & $(7.8-8.4)$ & $(7.8-8.3)$ \\
\hline \multirow{2}{*}{ Conductivity $\mu \mathrm{S} . \mathrm{cm}^{-1}$} & 278 & 434 & 468 & 432 \\
\hline & $(210-298)$ & $(380-796)$ & $(342-670)$ & $(310-543)$ \\
\hline Distance downstream of effluent input (km) & 0 & 2.5 & 5.5 & 12 \\
\hline
\end{tabular}


Table 2. Percentage frequency of occurrence of various macroinvertebrate taxa collected from four sites on the upper Rio Cobre, Jamaica. Values are expressed as a percentage of the total number of organisms collected at that site over the sampling period. Also shown is the total number of invertebrates collected at each site $(\mathrm{N})$, the taxonomic richness (TR), and mean values for two diversity indices. $+=<0.1 \%$. Last column shows the Functional Feeding Group (FFG) ascribed to each taxon. Key: $\mathrm{C}=$ collector $\mathrm{P}=$ predator, $\mathrm{S}=$ scraper, $\mathrm{SH}=$ shredder.

\begin{tabular}{|c|c|c|c|c|c|c|c|}
\hline \multicolumn{3}{|c|}{ Taxon/Site } & \multirow{2}{*}{$\begin{array}{c}\text { Black } \\
\text { River }\end{array}$} & \multirow{2}{*}{$\begin{array}{c}\text { Victoria } \\
2.3\end{array}$} & \multirow{2}{*}{$\begin{array}{c}\text { Linstead } \\
1.5\end{array}$} & \multirow{2}{*}{$\begin{array}{c}\text { Deeside } \\
2.1\end{array}$} & \multirow{2}{*}{$\frac{\text { FFG }}{\mathrm{P}}$} \\
\hline Turbellaria & Dugesidae & Girardia sp. & & & & & \\
\hline Oligochaeta & Naididae & Dero sp. & & 1.7 & 1.6 & & $\mathrm{C}$ \\
\hline Hirudinea & Glossiphonidae & Helobdella sp & 0.5 & 0.5 & 0.7 & & $\mathrm{C}$ \\
\hline Ephemeroptera & Baetidae & Baetis sp. & 0.5 & 28.2 & 30.0 & 9.8 & $\mathrm{C}$ \\
\hline Ephemeroptera & Caenidae & Caenis sp. & & 0.1 & 0.1 & & $\mathrm{C}$ \\
\hline Ephemeroptera & Leptophlebiidae & Hagenulus jamaicensis (Peters 1971) & 3.2 & & 0.1 & 0.1 & $\mathrm{C}$ \\
\hline Odonata & Coenagrionidae & Enallagma coecum & & 0.2 & 0.1 & & $\mathrm{P}$ \\
\hline Odonata & Libellulidae & Scapanea frontalis (Burmeister 1839) & 0.2 & 0.1 & 0.2 & 0.1 & $\mathrm{P}$ \\
\hline Odonata & Aeshnidae & Anax junius (Drury 1773) & & 0.1 & & & $\mathrm{P}$ \\
\hline Trichoptera & Hydropsychidae & Smicridea jamaicensis (Flint 1968) & 0.4 & 25.6 & 37.1 & 14.5 & $\mathrm{C}$ \\
\hline Trichoptera & Helicopsychidae & Helicopsyche ochthephila (Flint 1969) & 51.8 & 0.1 & 0.1 & 6.1 & $\mathrm{~S}$ \\
\hline Trichoptera & Glossosomatidae & Cubanoptila tridens (Botosaneanu 1998) & 22.6 & 0.2 & 5.3 & 11.9 & $\mathrm{~S}$ \\
\hline Trichoptera & Hydroptilidae & Oxytheria sp. & 0.1 & 0.8 & 0.2 & 0.1 & $\mathrm{~S}$ \\
\hline Trichoptera & Hydroptilidae & Ochrotrichia sp. & 1.5 & 1.1 & 2.3 & 0.6 & $\mathrm{~S}$ \\
\hline Trichoptera & Hydroptilidae & Alisotrichia sp. & & & & 0.8 & $\mathrm{~S}$ \\
\hline Trichoptera & Calaomoceratidae & Phylloicus farri (Flint 1968) & 0.3 & 0.1 & & 1.6 & SH \\
\hline Lepidoptera & Pyralidae & Paraponyx sp. & 0.1 & 1.8 & 0.9 & 12.9 & SH \\
\hline Lepidoptera & Pyralidae & Nymphula sp. & & & & 0.1 & SH \\
\hline Coleoptera & Gyrinidae & Dineutis longimanus (Olivier 1792) & 0.1 & 0.2 & 0.1 & & $\mathrm{P}$ \\
\hline Coleoptera & Elminthidae & Elmis filiformis (Darlington 1927) & 0.2 & 0.6 & 1.8 & 0.7 & $\mathrm{C}$ \\
\hline Coleoptera & Haliplidae & & & & 0.1 & & S \\
\hline Coleoptera & Hydrophilidae & Tropisternus lateralis (Fabricius 1775) & & 0.1 & 0.1 & & $\mathrm{P}$ \\
\hline Coleoptera & Dytiscidae & Bidessonotus sp. & & & 0.1 & & $\mathrm{P}$ \\
\hline Hemiptera & Veliidae & Rhagovelia tayloriella (Kirkaldy 1900) & & & & 0.1 & $\mathrm{P}$ \\
\hline Diptera & Chironomidae & Tanytarsus sp. & 2.9 & 3.4 & 1.9 & 8.9 & $\mathrm{C}$ \\
\hline Diptera & Ceratopogonidae & Bezzia sp. & 0.1 & 0.3 & 0.2 & 0.1 & $\mathrm{P}$ \\
\hline Diptera & Empdidae & Clinocera sp. & 0.1 & 0.1 & 0.1 & 0.1 & $\mathrm{P}$ \\
\hline Diptera & Simuliidae & Prosimulium sp. & & & & 0.6 & $\mathrm{P}$ \\
\hline Diptera & Dolichiopodidae & Dolichopus sp. & & & 0.1 & & $\mathrm{P}$ \\
\hline Diptera & Hyalellidae & Hyalella sp. & & 0.1 & & & SH \\
\hline Hydracarina & & & 0.1 & 0.1 & & 0.2 & $\mathrm{P}$ \\
\hline \multirow[t]{5}{*}{ Gastropoda } & Ancylidae & Ferrissia hendersoni (Walker 1925) & 0.1 & 3.8 & 2.2 & 2.9 & $\mathrm{~S}$ \\
\hline & Hydrobiidae & Spilochamys sp. & 4.0 & 0.4 & 0.5 & 1.6 & $\mathrm{~S}$ \\
\hline & Thiaridae & Thiara granifera (Lamarck 1882) & 5.8 & 1.8 & 2.4 & 15.5 & $\mathrm{~S}$ \\
\hline & Thiaridae & Melanoides tuberculata (Muller 1774) & 0.1 & 3.3 & 3.6 & 0.1 & $\mathrm{~S}$ \\
\hline & Physidae & Physella jamaicensis Adams 1851 & 0.1 & 12.2 & 3.8 & 5.0 & $\mathrm{~S}$ \\
\hline Bivalvia & Sphaeridae & & 0.2 & & & 1.4 & $\mathrm{C}$ \\
\hline Ostracoda & & & 2.2 & 11.5 & 1.9 & 1.1 & $\mathrm{C}$ \\
\hline $\mathrm{N}$ & & & 7331 & 18,577 & 23,819 & 4354 & \\
\hline TR & & & 25 & 29 & 29 & 26 & \\
\hline $\begin{array}{l}\text { Shannon } \\
\text { Weaver }\end{array}$ & & & 0.56 & 0.79 & 0.71 & 0.87 & \\
\hline Simpsons & & & 0.58 & 0.73 & 0.67 & 0.79 & \\
\hline
\end{tabular}




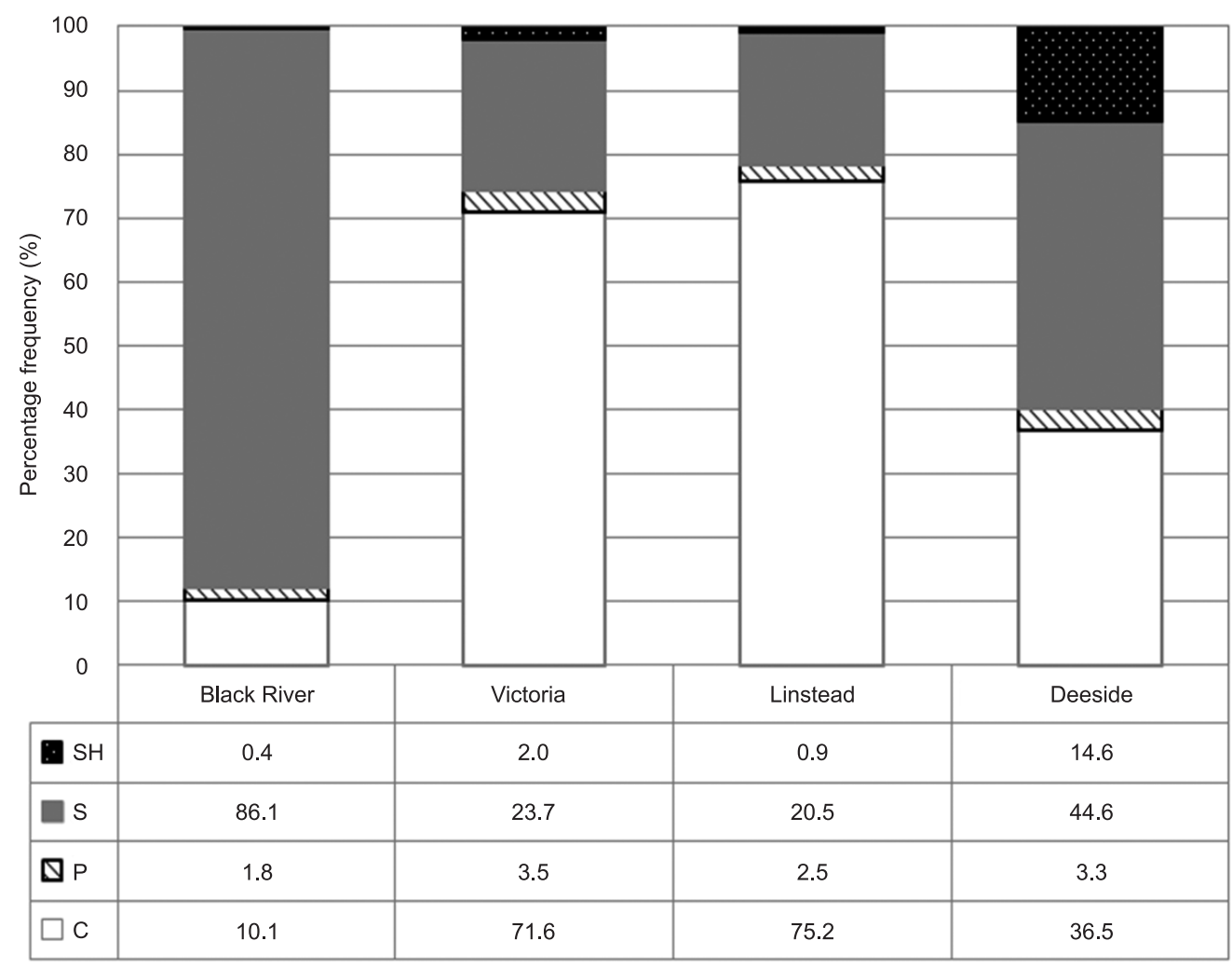

Figure 2. Comparison of the percentage frequency of total macroinvertebrates in the four main Functional Feeding Groups at four sites on the upper Rio Cobre, Jamaica. Key: $\mathrm{C}=$ collector $\mathrm{P}=$ predator, $\mathrm{S}=$ scraper, $\mathrm{SH}=$ shredder.

Table 3. Mean monthly percentage similarity in taxonomic composition of macroinvertebrate samples from four sites on the upper Rio Cobre.

\begin{tabular}{cccc}
\hline & Black river & Victoria & Linstead \\
\hline Victoria & 45 & & \\
Linstead & 52 & 83 & \\
Deeside & 90 & 64 & 72 \\
\hline
\end{tabular}

temperature. The Black River site is on a first order stream, whereas the others are on the main river which is of a higher stream order, therefore the proportion of water exposed to sunlight will be less than at the other sites. However as the temperature of the bauxite effluent frequently exceeds $30{ }^{\circ} \mathrm{C}$ (Andrews et al. 2001), the effects of this may still be apparent at the downstream sites.

Higher conductivity at the downstream sites is consistent with the elevated sodium and aluminium levels noted in the effluent (Parkin 1993) and with conductivity values recorded at the point of effluent input in this study (mean $659 \mu \mathrm{S} . \mathrm{cm}^{-1}$, standard error $105 \mu \mathrm{S} . \mathrm{cm}^{-1}$, range 369 to $1476 \mu \mathrm{S} . \mathrm{cm}^{-1}, \mathrm{n}=12$ ), suggesting that there is a detectable downstream impact from effluent input.

Aluminium is rarely found in an active form in freshwaters. Aluminium ions are generally considered to be toxic to aquatic life but are known to form organic and inorganic complexes (Abel 1996). Much of the aluminium is released from these complexes in acidified conditions and the relationship between acidification of freshwaters and toxicity of the element to fishes at $\mathrm{pH}<5.0$ is well established. Less is known about the effects at natural $\mathrm{pH}$ in the alkaline range. Three "types" of aluminium species have been recognised as having biological significance (Driscoll 1984). Of these, the inorganic monomeric labile fraction is toxic to fish. (Driscoll et al. 1980) At $\mathrm{pH}$ 's $>7.5$, this exists mainly as aluminium hydroxide (Smith 1971). Solubility of aluminium and toxicity to organisms is generally considered to increase once $\mathrm{pH}$ exceeds 7.0 (Abel 1996). It is therefore likely that aluminium species with toxic effects on biological material would occur at the waste impacted sites in this study, although Greenway and Parkin (1993) demonstrated that increases in aluminium content in the Rio Cobre sediment did not persist far downstream below the point of effluent input.

Bauxite processing waste is a combination of the unwanted components of the bauxite ore once aluminium has been extracted from it (mainly oxides of iron, silicon, titanium, manganese and some aluminium oxide - "red mud") and waste chemicals used in the extraction process (mainly sodium hydroxide). The aluminium oxide forms a colloidal solution and is known to adsorb organic acids such as fulvic and humic acid (Davis 1980). From a biological perspective this suspension causes an increase in turbidity of the receiving river. Large volumes of suspended particles (red mud) are eventually deposited as flocs in regions of low turbulence. Episodic release of bauxite processing liquor results in precipitation of calcium carbonate which is deposited downstream as calcite sediment (Andrews et al. 2001). Both events lead to habitat alteration. At Victoria and Linstead sites, flocculent mud deposits are abundant and any disturbance of the substrate causes resuspension of deposited material. Large volumes of in-stream aquatic macrophytes (Potamogeton fluvitans and Elodea canadiensis, principally) become established on these mud deposits (pers. obs. E. Hyslop). These changes in conditions, flocculent mud deposits, calcite deposition and in-stream vegetation can explain the divergence in faunal composition at impacted sites when compared to Black River (Table 1 and Figure 2). For example, the odonates, Enallagma coccum and Anax junius, which occur only at Victoria and Linstead, are associated with vegetation. 
Physella jamaicensis and ostracods are also largely found in plant beds. Aquatic macrophytes fulfil several important functions which may promote species richness in the invertebrate community as they form a refuge for many species and act as a trap for organic material as well as increasing habitat heterogeneity by disrupting flow patterns (Allen and Castillo 2008).

Sodium hydroxide input would be expected to increase $\mathrm{pH}$, but this was not detected at impacted sites (Table 1). The water of the Rio Cobre has high levels of hardness (range 88-128 ppm $\mathrm{CaCO}_{3}$ ) (Fender 2001). The high calcium ion concentration provides buffering capacity and any fluctuations in $\mathrm{pH}$ and also $\mathrm{pH}$-dependent release of aluminium due to addition of bauxite waste would be minimised. It is likely that the sodium ions contribute to the elevated conductivity at impacted sites as was observed by Andrews et al. (2001).

Comparing the composition of the invertebrate fauna at the four sites, it is evident that the greatest similarity exists between Black river and Deeside, and Victoria and Linstead (Table 3). Taking into account the proportions of the component taxa (Figure 1), then Black river is clearly the outlier in relation to the other three sites. The invertebrate community at Deeside is more diverse when compared to the Victoria and Linstead sites, where there is co-dominance by $S$. jamaicensis and Baetis. At Black River however, using either measure of diversity, the lowest mean value for diversity was recorded. Black River is a side stream of lower habitat complexity and stream order than the other three sites which are located on the main river. This factor would undoubtedly have an impact on community composition. Unfortunately, it was not possible to locate an uncontaminated site on the main river channel above the point of entry of the bauxite waste. The dominance of two cased trichopteran larvae species at Black River contributes to the low diversity scores. The co-dominance of these two caddis families has been recognized in other tropical regions (Dudgeon 1999). Larvae of Glossosomatidae require lower water temperatures and well oxygenated conditions (Mackie 2001) which might explain their occurrence at this site. $C$. tridens is categorized as a scraper, as is H. ochthephilia and also Haegulus jamaicensis (Fam. Leptophlebiidae), (Peters 1971).

The two thiarid snails recorded from the samples are invasive species now widely established in Jamaica and throughout the wider Caribbean region (eg Pointier 2001). T. granifera is much more widely distributed in Jamaican freshwaters than M. tuberculata (Hyslop 2003). The dominance of the latter species at the Victoria and Linstead sites might be explained by greater tolerance by M. tuberculata of metal contamination or suspended material or both (Berry \& Kadri 1974, Thompson 1984, Chaniotis et al. 1980).

There is a high level of similarity in FFG proportions between the Victoria and Linstead sites with collectors predominating, whereas the importance of scrapers is much greater at the other 2 sites, to the extent that this group predominates in the Black River invertebrate community. Scrapers are poorly represented at the other three sites (Figure 2) when compared to Black River., perhaps due to flocculent deposits limiting the growth of periphyton.

According to Jacobsen et al. (2008), the genus Baetis is in urgent need of taxonomic revision and subdivision. Baetis spp. may be regarded as collector/gatherers or scrapers (Meritt and Cummins 1996) and have been classified as a scraper/gatherer in the tropical context (Yule 2009). A similar position was taken by Shepard and Minshall (1984). Tomanova (2006), examining the functional feeding groups of several genera of Baetidae, (although not Baetis), in Bolivian streams, placed them in both the collector/gatherer and scraper categories. This ambiguity means that it is difficult to draw rigid conclusions on the abundance of functional feeding groups at the Victoria and Linstead sites. Examination of the mouthparts of the Baetis specimens collected did not reveal the existence of hardened structures which have been deemed indicative of the "scraper" category (McShafferty \& McCafferty 1986). We therefore chose to classify Baetis as a collector/gatherer but some qualification needs to be applied to this categorization. The lack of specialized feeding habits in Baetis may contribute to the resilience of this taxon to disturbance and help explain its abundance at the Victoria and Linstead sites. S. jamaicensis, is recognized as a collector/filterer which mainly utilizes CPOM (Boon 1988). A ready supply of particulate material would be available at the Victoria and Linstead sites but this would be a poor food source. Lower levels of suspended material on the other hand, would tend to promote the growth of periphyton, a food source for scrapers, hence the abundance of this FFG at Black River. The oxygen requirements of members of the Hydropsychidae are quite low (Mackie 2001) which would help explain the predominance of S. jamaicensis at Victoria.

While this study does not provide evidence of a direct impact of bauxite processing waste on the macroinvertebrate community through metallic pollution, and while the results need to be interpreted with caution due to the limitations of a comparison between the impacted sites and a location which is not directly equivalent, it does seem to indicate that suspended material from the waste indirectly influences species composition at sites below the point of input by causing habitat alteration with concomitant changes in invertebrate fauna. Dominance of S. jamaicensis and Baetis at the most heavily impacted sites and an under-representation of the scraper functional feeding group appear to be the main effects

\section{References}

ABEL, P.B. 1996. Water pollution biology. Taylor and Francis, London.

ALLEN, J.D. \& CASTILLO, M.M. 2008. Stream ecology: Structure and function of running waters. 2nd ed. Springer, Netherlands.

ANDREWS, J.E., GREENAWAY, A.M., DENNIS, P.F. \& BARBES-LESLIE, D.A. 2001. Isotopic effects on inorganic carbon in a tropical river caused by caustic discharges from bauxite processing. Appl. Geochem. 16:197-206. http://dx.doi.org/10.1016/S0883-2927(00)00033-0

BERRY, A.J. \& KADRI, A.B.H. 1974. Reproduction in the Malayan freshwater cerithiacean gastropod Melanoides tuberculata. J. Zool. 172:369-381. http://dx.doi.org/10.1111/j.1469-7998.1974.tb04113.x

BOON, P.J., JUPP, B.P., \& LEE, D.G. 1986. The benthic ecology of rivers in the Blue Mountains (Jamaica) prior to construction of a water regulation scheme. Arch. Hydrobiol 74:315-355

BOON, P.J. 1988. Notes on the distribution and biology of Smicridea (Trichoptera: Hydropsychidae) in Jamaica. Arch. Hydrobiol. 111:423-433.

CAIN, D.J., LUOMA, S.N., CARTER, J.L. \& FEND, S.V. 1992. Aquatic insects as bioindicators of trace element contamination in cobble-bottom rivers and streams. Can. J. Fish Aquat. Sci. 49:2141-2154 http://dx.doi. org/10.1139/f92-237

CAIRNS, J. \& PRATT, J.R. 1993. A history of biological monitoring using benthic macroinvertebrates. In FreshwaterBiomonitoring and benthic Macroinvertebrates (D.M. Rosenberg \& V.H. Resh, eds.). Chapman and Hall, New York

CALLISTO, M., ESTEVES, F.A., GONÇALVES, J.F. \&. LEAL, J.J.F. 1998. Impact of bauxite tailings on the distribution of benthic macrofauna in a small river ('igarapé') in Central Amazonia, Brazil. J. Kans. Entomol. Soc. 71(4):447-455.

CHANIOTIS, B.N., BUTLER, J.M., FERGUSON, F.F. \& JOBIN, W.R. 1980. Thermal tolerance, desiccation and humidity reactions of Thiara (Tarebia) granifera mauiensis (Gastropoda: Thiaridae), host of the Asiatic lung fluke disease. Caribb. J. Sci. 16:91-93.

CLEMENTS, W. 1994. Benthic Invertebrate Community Responses to Heavy Metals in the Upper Arkansas River Basin, Colorado. J. N. Am. Benthol. Soc.13:30-44. http://dx.doi.org/10.2307/1467263 
CUMMINS, K.W. 1995. Invertebrates. In The rivers handbook (P. Calow \& G.E. Petts, eds.). Blackwell, Oxford. p.234-250.

DAVIS, J.A. 1980. Adsorption of natural organic matter from freshwater environments by aluminium oxide. In Contaminants and sediments (R.A. Baker ed.). Ann Arbor. Sci. Publ. Inc. 2:279-303.

DRISCOLL, C.T., BAKER, J.P., BISOGNI, J.J. \& SCHOFIELD, C.L. 1980. Effect of aluminium speciation on fish in dilute acidified waters. Nature 284:161-164. http://dx.doi.org/10.1038/284161a0

DRISCOLL, C.T. 1984. A procedure for the fractionation of aqueous aluminium in dilute acidic waters. Int. J. Environ. An. Ch. 16:267-283. http://dx.doi.org/10.1080/03067318408076957

DUDGEON, D. 1999. Tropical Asian streams: zoobenthos, ecology and conservation. Hong Kong University Press, Hong Kong.

FENDER, A. 2001. Evaluation of the benthic macroinvertebrate composition of the Rio Cobre and selected tributaries with special emphasis on the family Thiaridae. Master's thesis, University of the West Indies, Mona, Jamaica.

FONSECA, J.J.L. \& ESTEVES, F.A. 1999. Influence of bauxite tailings on the structure of the benthic macroinvertebrate community in an Amazonian Lake (Lago Batata, Pará - Brazil). Rev. Bras. Biol. 59:397-405. http:// dx.doi.org/10.1590/S0034-71081999000300004

GOTO, D. \& WALLACE, W.G. 2009. Biodiversity loss in benthic macroinfaunal communities and its consequence for organic mercury trophic availability to benthivorous predators in the lower Hudson River estuary, USA. Marine Pollut. Bull. 58:1909-1915 PMid:19857879. http:// dx.doi.org/10.1016/j.marpolbul.2009.09.032

GREENAWAY, A.M. \& PARKIN, G.N.L. 1993. Water and sediment analyses on samples from the Rio Cobre. Jamaican J. Sci. Technol. 4:1-16

HYSLOP, E.J. 2003. Additions to the freshwater malacofauna of Jamaica. Rev. Biol. Trop. 51:262-263.

JACOBSEN, D., CRESSA, C., MATHOKO, J.M. \& DUDGEON, D. 2008. Macroinvertebrates: composition, life histories and production. In Tropical stream ecology (D. Dudgeon, ed.). Elsevier, Amsterdam, p.65-105. http://dx.doi.org/10.1016/B978-012088449-0.50006-6

LIBRARY OF CONGRESS. Industry. http://countrystudies.us/caribbeanislands/30.htm (último acesso em 07/05/2011).

LYNCH, T.R., POPP, C.J. \& JACOBI, G.Z. 1988. Aquatic insects as environmental monitors of trace metal contamination: Red River, New Mexico. Water, Air Soil Poll. 42:19-31. http://dx.doi.org/10.1007/ BF00282388

McSHAFFERTY, D. \& McCAFFERTY, W.P. 1986. Feeding behavior of Stenonema interpunctatum (Ephemeroptera:Heptageniidae). J. N. Am. Benthol. Soc. 22:359-370.

MACKIE, G.L. 2001. Applied aquatic ecosystem concepts. Kendall/Hunt, Iowa.
MARET, T.R., CAIN, D.J., MACCOY, D.E \&. SHORT, T.M. 2003. Response of benthic invertebrate assemblages to metal exposure and bioaccumulation associated with hard-rock mining in northwestern streams, USA. J. N. Am. Benthol. Soc. 22: 598-620. http://dx.doi. org/10.2307/1468356

MERRIT, R.W. \& CUMMINS, K.W. 1996. An Introduction to the Aquatic Insects of North America. Kendall/Hunt, Iowa.

PARKIN, G. 1993. Effect of bauxite/alumina waste on the Rio Cobre and its tributaries. Master's thesis, University of the West Indies, Mona, Jamaica.

PETERS, W.L. 1971. A revision of the Leptophlebiidae of the West Indies (Ephemeroptera). Smith. Contrib. Zool. 62:1-48 http://dx.doi. org/10.5479/si.00810282.62

POINTIER, J.P. 2001. Invading freshwater snails and biological control in Martinique island, French West Indies. Mem. I. Oswaldo Cruz 96:67-74. http://dx.doi.org/10.1590/S0074-02762001000900009

SHEPARD, R.B. \& MINSHALL, G.W. 1984. Selection of fine-particulate foods by some stream insects under laboratory conditions. Am. Midl. Nat. 111:23-32. http://dx.doi.org/10.2307/2425538

SØRENSEN, T. 1957. A method of establishing groups of equal amplitude in plant sociology based on similarity of species and its application to analyses of the vegetation on Danish commons. Biol. Skrif. 5:1-34.

SMITH, R.W. 1971. Relations among equilibrium and non-equilibrium aqueous species of aluminium hydroxyl complexes. Adv. Chem. Ser. 106:250-269 http://dx.doi.org/10.1021/ba-1971-0106.ch010

SPRAGUE, J.B., ELSON, P.F. \& SAUNDERS, R.L. 1965. Sublethal copperzinc pollution in a salmon river - a field and laboratory study. Int. J. Air Water Poll. 9:531-543

THOMPSON, F.G. 1984. The freshwater snails of Florida: A manual for identification. University of Florida Press, Gainesville.

TOMANOVA, S., GOITIA, E. \& HELESIC, J. 2006. Trophic levels and functional feeding groups of macroinvertebrates in neotropical streams. Hydrobiologia 556:252-264 http://dx.doi.org/10.1007/s10750-0051255-5

US DEPARTMENT OF STATE. Background note: Jamaica 9th august 2010 www.state.gov/r/pa/ei/bgn/2032.htm (último acesso em 07/05/2011).

WAYLAND, M. \& CROSLEY, R. 2006. Selenium and other trace elements in aquatic insects in coal mine-affected stream in the Rocky mountains of Alberta, Canada. Arch. Environ. Contam. Toxicol. 50:511-522 PMid:16446991. http://dx.doi.org/10.1007/s00244-005-0114-8

WINNER, R.W., BOESEL, M.W. \& FARRELL, P.M. 1980. Insect community structure as an index of heavy-metal pollution in lotic ecosystems. Can. J. Fish. Aquat. Sci. 37:647-655. http://dx.doi.org/10.1139/f80-081

YULE, C.M. 1996. Trophic relationship and food webs of the benthic invertebrate fauna of two aseasonal tropical streams in Bougainville Island, Papua New Guinea. J. Trop. Ecol. 12:517-534. http://dx.doi. org/10.1017/S0266467400009755 